\title{
History Textbook Writing in Post- conflict Societies: From Battlefield to Site and Means of Conflict Transformation
}

\author{
Denise Bentrovato
}

Societies emerging from violent conflict face daunting challenges. One of the many challenges they face relates to the question of how to deal with the divisive past in ways that promote peace and reconciliation. The profusion of transitional justice (TJ) practices and of related scholarship since the 1990s evidences the systematic attention recently given to this question in post-conflict societies (Buckley-Zistel et al. 2014; Clark and Palmer 2012). TJ measures, such as truth commissions, tribunals, official apologies, reparation programmes and institutional reforms, have increasingly become key elements in the stock of interventions designed to help societies come to terms with their past in order to break cycles of violence and prevent its recurrence. The expansion of the field of TJ has been accompanied by an increasing appreciation of the role of education in the nonrepetition of violence (Leach and Dunne 2007; Smith 2010). A growing

The author is grateful to Luigi Cajani, Alan McCully and Falk Pingel for their valuable comments on this paper.

D. Bentrovato $(\square)$

University of Pretoria, Pretoria, South Africa

e-mail: denise.bentrovato@up.ac.za

(C) The Author(s) 2017

C. Psaltis et al. (eds.), History Education and Conflict Transformation, DOI 10.1007/978-3-319-54681-0_2 
body of research has consequently emerged that examines the distinct role of history education in conflict and peace, inspiring lively debates on how to teach history after conflict (Bentrovato et al. 2016; Cole 2007; Paulson 2015). Embedded in these debates, this chapter focuses on one particular aspect of post-conflict history education, namely school textbooks-a central element in history teaching practices across the globe, though only one among various sources within the "complex medial space" (Lässig 2013: 4) that may shape historical consciousness (Rüsen 2004; Seixas 2004). More specifically, it examines the revision and development of history textbooks as one aspect, often marginalised in scholarly research, in the plethora of interventions designed to promote reconciliation in societies transitioning from violent conflict to peace and democracy.

Drawing from a wide range of case-studies from around the world as its empirical base, this chapter reviews past and present work around history textbook writing in divided and post-conflict societies in order to reflect upon the conciliatory value and limitations of current practices in this field. Its aim is to shed light on key approaches, challenges and opportunities related to textbook work in the context and aftermath of conflict and mass violence, and also on actors and conditions that have had an influence on related processes and outcomes. The chapter starts from the premise of the complex role of history textbooks in conflict and peace before examining recent experiences in textbook writing and takes stock of some of the different models and underlying assumptions that have marked this field. A narrative framework is adopted to structure the analysis of the processes and outcomes characterising these endeavours. Within this framework, the chapter first examines the promises and pitfalls of a variety of prominent short-term and longer-term approaches to post-conflict textbook work, thereby focusing on the narrative strategies employed to deal with contentious and potentially divisive histories in the wake of intergroup conflict. Moving beyond a focus on the concrete outcomes of textbook projects, it then relies on the "conflict transformation" paradigm to highlight the less tangible conciliatory value inherent in the performative dimension of these projects. It thereby draws attention to the transformative potential of communicative processes involved in collaborative textbook work that is geared towards the production of inclusive, multiperspective educational resources.

The chapter argues that, while history textbook revision poses daunting challenges for societies emerging from recent violent conflict, often serving as a battlefield for opposing narratives and interests, such 
processes also offer largely unexploited opportunities as potential sites and means of conflict transformation. Specifically, it suggests that the added value of post-conflict textbook work lies in its potential to provide a context for positive intergroup engagement and dialogue which could facilitate reconciliation, and the intrinsic "redefinition of relationships" (Lederach 2001: 847), through encouraging a process of "narrative transformation." Ultimately, this study aims to contribute to further mapping and conceptualising an eclectic and still undertheorised field that has been largely driven by practice as well as to distil lessons for the purpose of enhancing the role of such initiatives in processes of peacebuilding and reconciliation.

\section{The Janus-Face of History Textbooks in Conflict and Peace}

History textbooks are not of little significance. Their conspicuous role in society has been underscored by extensive textbook research describing them as powerful "cultural artefacts" that have traditionally served as conveyors of official knowledge (Apple 1993; Apple and ChristianSmith 1991; Foster and Crawford 2006; Marsden 2001; Nicholls 2006). Across the globe, they have functioned as central instruments of nationbuilding and citizenship formation and as important sites for the construction and transmission of collective identities and memories and of particular concepts of nationhood (Carretero 2011; Williams 2014). As such, history textbooks have been commonly politicised, becoming a significant pawn and a key stake in struggles and conflicts over identity and power. Critical textbook studies have shown that, as a result and a reflection of these struggles, their content, far from being neutral, has reproduced and legitimised the beliefs, values and norms of dominant groups in society (e.g. Apple and Christian-Smith 1991).

Growing research into the politics of history textbooks has indicated the conflict potential of these powerful media. Time and again, their role in promoting attachment to a particular "imagined community" (Anderson 1991) has been fulfilled through glorification of some and marginalisation and vilification of others. In the aftermath of violent conflict, history textbooks are frequently found to have played a particularly deleterious role in society by conveying and cementing prejudice, stereotypes and enemy images through their dissemination of largely mythical narratives that depict in- and outgroup identities as primordial, 
monolithic and antagonistic. They have construed and legitimised images of age-old intergroup enmity and of ingroup natural superiority, collective victimhood, heroism, and historical entitlement to territory, power and resources, while presenting negative portrayals of the "other" (Bentrovato et al. 2016; Dimou 2009; EUROMID 2006; Richter 2008; Vickers and Jones 2005). In so doing, history textbooks have reinforced antagonistic perceptions and inequalities which, in the conflict transformation literature, have been identified as characterising protracted identity-based conflict in deeply divided societies (Bar-Tal 2000; Kriesberg 2004; Lederach 1997; Oberschall 2007).

Conversely, as observed by various authors, history textbooks can also "help transform society by challenging the deep-rooted prejudices and inequalities at the heart of the conflict" (Leach and Dunne 2007: 11). With history textbooks having regularly been seen as a factor contributing to conflict, post-war interventions have often included the establishment of bodies with a mandate to re-examine textbooks in order to screen and purge them of objectionable content and to (re)write more appropriate materials or produce guidelines for this purpose. These activities have been considered an important confidence-building and peacebuilding strategy able to contribute to the deconstruction of negative perceptions and the promotion of dialogue, mutual understanding and social cohesion. Today these activities can count on a longstanding "conciliatory tradition" of textbook work (Foster 2011), which, developed in Europe especially after World War II, has inspired both scholarship and practice around the world (Pingel 2008, 2010; Stöber 2013). Historically promoted to advance interstate peace and international understanding, traditional goals of conciliatory textbook work have consisted in convening historians and teachers from across the divide with a view to "disarming" and "decontaminating" textbooks and to producing new resources "so that they (a) are underpinned by common historical understandings of the past and (b) are more sensitive to the histories of other nations" (Foster 2011: 7).

Since then, textbook activities have slowly found a place in peace agreements and TJ processes in contexts of intrastate conflicts and their resolution. The 1989 Taif peace agreement, for instance, which ended civil war in Lebanon after fifteen years of sectarian strife, explicitly, though largely unsuccessfully (Daher 2012; Kriener 2012), urged the revision of curricula "in a manner that strengthens national belonging, fusion, spiritual and cultural openness, and that unifies textbooks 
on the subjects of history and national education" (art. III.F.5). The peacebuilding role of history education and textbooks is also both implicitly and explicitly recognised in key TJ documents issued by the United Nations, which hint at the need to expediently revise and update textbooks to accurately deal with a violent past. Particularly, the UN Impunity and Reparation Principles respectively highlight the importance of educative measures to facilitate "A people's knowledge of the history of its oppression" in fulfilment of a state's "duty to preserve memory" and counter impunity (United Nations Commission on Human Rights 2005), and, on that premise, further call for the "[i]nclusion of an accurate account of the violations [...] in educational material at all levels" as a symbolic reparation measure for victims of historical wrongs (United Nations General Assembly 2006, in De Baets 2015: 18).

Fulfilling these demands and expectations is not an easy task, but rather one that is itself ridden with conflict. History textbook revision is an inherently contested and selective process conducted and influenced "by real people with real interests" (Apple 1993: 46). It entails negotiations and deliberations, which may provoke tensions that are part and parcel of struggles for recognition and legitimacy. In societies emerging from violent intergroup conflict, history textbook revision faces particular challenges. Here, the contentions surrounding the selection of textbook content are compounded by a meta-conflict that is typically manifest in the existence of viscerally held, one-sided and mutually contested narratives of victimisation. Competing group narratives may diverge regarding the causes of conflict, the number and identity of the victims, actors' roles and responsibilities, and the motivations, legitimacy and implications of their actions. They also commonly differ as to the terminology they use to define violent events, each presenting different connotations and meanings. Definitions of one and the same event have ranged from "liberation" to "aggression", "invasion" or "occupation", and from "incident" or "crisis" to "civil war", "killings", "massacre" or "genocide". Daniel Bar-Tal poignantly summarises this predicament by suggesting that "Over the years, groups involved in conflict selectively form collective memories about the conflict. On the one hand, they focus mainly on the other side's responsibility for the outbreak and continuation of the conflict and its misdeeds, violence and atrocities; on the other hand, they concentrate on their own self-justification, selfrighteousness, glorification, and victimization" (Bar-Tal 2003: 78; see also Cairns and Roe 2003). In such contexts, the fundamental lack of 
consensus on the shared but divisive past is often recognised as an obstacle to reconciliation. Yet, at the same time, efforts aimed at confronting and teaching the violent past and its various controversies are commonly feared as possibly destabilising for the fragile peace that tends to characterise post-conflict societies.

As will be outlined in the next sections, post-conflict societies have taken various routes in responding to the demands and challenges related to teaching younger generations about histories of violent intergroup conflict through textbooks. The variety of approaches and strategies adopted in this field includes shorter-term stopgap measures often promoting narrative silence, evasion or elision, notably through the establishment of moratoria and the banning or the emergency revision of existing textbooks. It also includes longer-term textbook development work, espousing different concepts and methods, including singlenarrative or multinarrative and multiperspective approaches. As a result of these various strategies, in different contexts violent histories will be shown to have been alternatively sidestepped, repressed, sanitised, mystified or meaningfully dealt with in post-conflict school textbooks, possibly affecting intergroup reconciliation.

\section{Short- and Medium-Term Textbook Revision: Narrative Silence, Evasion ANd Elision}

\section{History Textbooks and Post-war Moratoria}

Post-conflict societies face two immediate concerns when it comes to history textbooks: one is to review and revise existent materials to eliminate biased and conflict-ridden content; the other is to update their content drawing on recent historical research and to include discussions on the more recent past. This represents a difficult and time-consuming endeavour, especially so in cases where both curricula and textbooks may not have been revised for decades. Confronted with these tasks, numerous countries around the world have opted, at least temporarily, for an amnesiac or evasive approach to history education, particularly in relation to the most contested and painful recent past. As Alan McCully (2012) observes, after conflict, "Dealing with the recent past is especially problematic because the situation is still heavily disputed, raw, and characterized by personal trauma, anger, and grief” (p. 154). 
Against this backdrop, a common strategy in the immediate aftermath of violent conflict has been the establishment of moratoria, namely "the temporary suspension of history education or its recent history segment, including its textbooks" (De Baets 2015: 6). This measure was officially implemented, for instance, in Afghanistan (Sarwari 2012), Bosnia and Herzegovina (Ahonen 2013), Cambodia (Dy 2008, 2013), Croatia (Koren and Baranović 2009), Guatemala (Bellino 2014), Lebanon (van Ommering 2015), Libya (Duncan 2011), Rwanda (Bentrovato 2015) and South Africa (Weldon 2010) - their time span varying from a few years to several decades. While countries such as Cambodia, Croatia, Rwanda and South Africa have gradually moved away from narrative silence and have variously dealt with their past in schools, recent conflict remains largely unaddressed in compulsory history education in all the other cases mentioned, despite ongoing efforts to revise curricula and textbooks. In yet other contexts, including numerous countries in subSaharan Africa such as Burundi and Sierra Leone, silence surrounding the violent past, while not officially sanctioned by a formal moratorium, has been virtually maintained in the classrooms due to the continuing lack of updated official history curricula and textbooks. Here, the turbulent post-colonial past is either omitted outright or, at best, is reduced to lists of names and dates as a way to avoid controversy (Bentrovato 2017).

The choice of a "rhetoric of silence" (Ondek and Laurence 1993) underlying official post-conflict textbook work has been determined by a number of considerations, most of which are underpinned by a belief, or a political pretext, relating to the benefit of the passage of time (see also De Baets 2015). At least four main arguments have been regularly raised by stakeholders around the world to legitimise this option. First, this approach has been rationalised as a necessity for national healing and reconciliation by supposedly allowing time for society to come to terms with the past. Evasive strategies towards history textbooks have been dictated by concerns that, in the immediate aftermath of violent conflict, when wounds are still fresh and memories and legacies of violence pervasive, confronting the painful past may be too sensitive and may provoke controversy and commotion that could hamper intergroup reconciliation. Such concerns underlying the choice to temporarily edit out historical conflict seem justified by research showing that revisiting traumatic events can be shattering for those who lived through the violence, be they survivors, perpetrators or bystanders (e.g. Hamber 2009), 
as well as their offspring (Danieli 1998). Consequently, a belief has been expressed in the desirability of allowing sufficient temporal distance in order for later generations, less constrained by a too recent perspective which may lock societies into Manichean discourses, to take on the task of addressing the violent past in a more objective and less emotional manner. A second argument, equally related to fears connected to the risk of jeopardising peace, concerns political constraints to the possibility of objectively and safely confronting the past when actors who were involved in the conflict still hold powerful positions. The weight of this particular consideration is largely contingent on the ways in which conflict ends, be it by unilateral military victory or negotiated agreement, and on the subsequent power constellations. A third argument for a temporarily evasive approach underscores the need to allow sufficient time for scientific and legal investigation and documentation to uncover "the truth" and to reach consensus about the past. This argument typically highlights the role of TJ mechanisms as well as historians in providing society with answers to open historical questions and controversies before new textbooks can be developed. A fourth reason concerns more pragmatic issues. In the short term, post-war countries commonly face so many different challenges, including insecurity, poverty and institutional weakness, that history textbook revision may not be considered as a priority or even a possibility. Within the education sector alone, postconflict countries may face the challenge of having to rehabilitate a derelict system following the destruction of educational facilities and the loss or displacement of educational personnel and academics, a group often deliberately targeted during armed conflict (GCPEA 2014; UNESCO 2011; World Bank 2005). Undoubtedly, behind such arguments are often vested interests of political actors concerned with delaying all confrontation with the past in order to secure power and legitimacy.

While they may be dictated by more or less legitimate concerns, evasive approaches to post-conflict history textbook revision are not uncontroversial or unproblematic. For those who consider themselves as victims of historical wrongs, textbook silence on their past experience of suffering may be resented as renewed injustice and may thus provide political entrepreneurs with a chance to manipulate grievances for their vested interests, thus perpetuating conflict. This cautionary note echoes the warnings widely articulated in the peace-and-conflict literature against the dangers to peace posed by a politics of oblivion, facilitating collective amnesia, denial and impunity, and scholars' virtual 
consensus on the importance of recognition and redress of historical injustice for intergroup reconciliation (e.g. Bar-Tal and Bennink 2004; Minow 1998). In Bosnia, for instance, the moratorium that was placed by the government on teaching the recent war was vehemently protested by opponents of this policy "as 'an attack on the truth" and "as a call for "lies and silence", hindering rather than promoting reconciliation (De Baets 2015: 12). Evasive strategies that leave the past unsettled, especially if for a longer period of time, need to be further applied with due caution as they may leave a vacuum providing fertile ground for entrenched polarisation. This vacuum may allow the unchallenged thriving of sectarian and partisan conflict narratives in society while forestalling opportunities for younger generations to critically examine and make sense of the past and its pervasive legacy. In the face of curricular and textbook silence, these narratives have indeed been found to be commonly embraced by young people, thus favouring societal rifts (Barton and McCully 2005; Van Ommering 2015). Against this backdrop, one may argue that evasive strategies are likely to be beneficial as long as they are pursued temporarily and the ensuing vacuum effectively serves the purpose of revising textbooks based on unobstructed academic research and unrestricted public debate. As warned by De Baets (2015), suspicion should be raised by prolonged evasive strategies, which might be "censorship-induced" and aimed at promoting "repressed memory", 'selective amnesia' and 'historical taboo'” (p. 24), which are unlikely to be conducive to reconciliation.

\section{"Emergency Textbooks" and the Removal of Objectionable Content}

Besides the establishment of moratoria and the temporary suspension of history textbooks, another short-term form of post-conflict activities consists in the instant elision of biased and objectionable content from existing textbooks. This measure has been widely recommended by the international community as a minimum standard of textbook quality to be upheld after violent conflict. The Guidance Notes on Teaching and Learning developed by the Inter-Agency Network for Education in Emergencies (2010), for instance, highlight the "immediate need" to expunge "conflict-inciting materials and ideologically-loaded content" from textbooks (p. 2).

This measure was famously applied in the immediate post-WWII era by the Allied Powers, who, upon their victory, either banned or purged 
of militaristic and ultra-nationalist content textbooks that had been used in countries belonging to the Axis Powers, notably Germany, Italy and Japan (UNESCO 1949). Similar strategies have been adopted more recently in the wake of civil wars, in some cases showing a level of interventionism reminiscent of the post-WWII experience. Such interventionist models of emergency textbook revision, initiated and controlled by international actors, have been applied in Bosnia, Afghanistan and Iraq. In Bosnia, the moratorium on the teaching of the recent war, which had been negotiated through the Office of the High Representative as the body overseeing the implementation of the civilian aspects of the 1995 Dayton peace agreement, was accompanied by the screening and removal of "offensive or misleading" content from the largely ethnonationalist textbooks that have characterised this country's segregated education system catering in parallel for Bosnian Serbs, Bosnian Croats and Bosniaks. This measure was leveraged by the Council of Europe, making it a requirement for the country's aspired membership in this body. Under the supervision of an international monitoring team, textbook passages that had been identified as being problematic by a commission equally representing the country's "constituent peoples" were either blacked out or annotated as being "currently under review". Such measures have not been without controversies, having provoked public outcry as well as arousing pupils' heightened curiosity towards the censored content (Pingel 2009; Torsti 2007).

In Afghanistan and Iraq, two countries that underwent US-led foreign military intervention, similar emergency strategies were driven and controlled by the US and the US Agency for International Development (USAID) as the sponsoring organisation. In Afghanistan, emergency textbook revisions, which were launched after the toppling of Taliban rule in 2001, were partly sponsored by the US Commander's Emergency Response Programme and were aimed at erasing propagandistic and militant textbook content, including Jihadist teachings, which USAID had previously supported in the context of the Cold War (Burde 2014). Similarly, the violent overthrow of Saddam Hussein in Iraq in 2003 was immediately followed by rapidly implemented textbook revisions that were conducted by UNESCO and UNICEF on behalf of the Coalition Provisional Authority (CPA). The emergency revisions entailed the "deBaathification" of textbooks, namely the erasure of Baath party ideology, as well as the elimination of signs of sectarianism and xenophobia (Al-Tikriti 2010; Rohde 2013a). Pointing to the influence of foreign 
actors on textbook revision, guidelines developed for this purpose in Iraq stipulated, among other things, the removal from textbooks of "any religious references in order to comply with the American constitution" as well as the erasure of "statements which promoted fighting, for example, against the USA or against Israel" (cited in Al-Tikriti 2010: 356).

International experiences in such contexts have illuminated a critical "tension between intervention and empowerment" (Lässig 2013: 10 ), with analyses indicating common failures to substantially engage local stakeholders and to ensure their ownership of processes and outcomes. This reported failure calls for caution if one considers that lack of ownership and empowerment is widely held to critically undermine the effectiveness and sustainability of any initiative, especially so if its aim is to positively affect local dynamics of peace and reconciliation (e.g. Lee and Özerdem 2015). This failure clearly emerges from a draft report on internationally driven textbook revision activities in Iraq issued by UNESCO - presently the leading international agency in this field in the country. The document points to tensions and serious "communication gap [s]" having emerged both between UNESCO and USAID officials, and, more crucially, between international actors and local partners. According to the report, the textbook revision guidelines "were not discussed properly among Iraqi and other education specialists", further remarking that "one should make sure that Iraqi educators are comfortable with the revision parameters" (cited in Al-Tikriti 2010: 356).

\section{Longer-Term Models of Post-conflict Textbook Work: Single- and Multinarrative Approaches}

In transitional societies, longer-term and more substantial post-conflict history textbook work is often principally left to a later date, at times coinciding with the end of the transition and the expected coming of a democratically elected government. ${ }^{1}$ In the post-transition phase, calls have been made to undertake a democratic process of post-conflict history textbook writing, which may include the development of materials jointly authored by representatives from across historical conflict lines. Such activities can count on a longstanding international tradition of conciliatory textbook work, originally undertaken between former enemies across state borders (Pingel 2008, 2010) and now increasingly "diffused" to also cater for the needs of societies emerging from intrastate conflict. Jointly developed resources that have been the result of long-term 
post-conflict textbook work are wide-ranging. They comprise recommendations or guidelines for textbook authors and editors; supplementary alternative materials or teaching units on specific historical topics in the form of teacher guides, source books or pupil's workbooks; and common textbooks aligned to curricular content. These collaborative projects, examples of which can be found across the globe, have been either government-sponsored or privately sponsored, or again they have been the fruit of state/non-state partnerships (Korostelina and Lässig 2013).

Many of the joint textbook development activities undertaken to date have resorted to relational approaches to history, their aim being to transcend narrow (ethno)national(ist) perspectives which tend to perpetuate conflict. Among the relational approaches adopted in these projects are comparative history, history of cultural transfers, transnational history, and histoire croisée or entangled history (Paulmann 1998; Werner and Zimmermann 2004)—all of which may or may not include explicit discussions on recent histories of violence. Paradigmatic examples of joint conciliatory textbook work include the experiences of the Franco-German and the German-Polish Textbook Commissions, two quasi-official bodies whose work culminated in the drafting of joint recommendations and the production of politically endorsed curricular resources based on a reciprocal critical review of textbooks in the respective countries (Defrance and Pfeil 2013; Lässig and Strobel 2013). Their notable work continues to inspire other societies around the world, most notably in East Asia, a region where history "textbook wars" have regularly made headlines, straining diplomatic relations (Mueller-Sainy 2011; Yang and Sin 2013). Whereas the conflict-ridden past and its related historical controversies have been intently addressed both in the FrancoGerman and the German-Polish cases, in other instances, such as in the Balkans, several non-governmental textbook projects have opted for a more evasive approach. While addressing intergroup relations from a historical perspective, they have focused, for instance, on a less contentious distant past or on selected themes in social and cultural history as strategies to promote rapprochement through the exploration of commonalities and instances of peaceful coexistence and cooperation (e.g. EUROCLIO 2008).

These projects today also differ as to whether they openly show and discuss, or rather "hide", controversy when addressing and narrating the contentious past. On this basis, two main alternative narrative approaches have been adopted in collaborative textbook projects: a traditional 
single-narrative approach, presenting a mutually accepted "consensual", "bridging" or "compromise narrative" that synthetises common understandings of a shared or connected history; and a pluralistic multinarrative and multiperspective approach, which refrains from supplying an authoritative narrative, instead presenting contrasting narratives for critical enquiry. As outlined below, these different approaches to textbook revision and development reflect divergent perceptions of the nature, function and value of history education in society and, more specifically, of the ways history textbooks can foster peace.

\section{The Elusive Value of the Single-Narrative Approach: Consensus or Hegemonic History?}

The single-narrative approach to history textbook work entails collaboratively constructing, through negotiation and compromise, a mutually agreed-upon narrative, which harmonises the perspectives of conflicting parties. Originally prevalent in international textbook projects, this consensus-based model has entailed joint efforts to negotiate a common narrative, whereby special care is given to both eliminating enemy images, bias and stereotypes, and emphasising historical elements possibly conducive to reconciliation, such as positive interactions in history (Pingel 2008). In countries emerging from civil strife and marked by profound societal and historical rifts, the conventional single-narrative approach has often been favoured as a strategy to foster unity and social cohesion in response to an acutely felt need to mend the torn social fabric. This concern is demonstrated in recent research indicating the prominence of traditional, national(istic) single narratives in textbooks developed in post-conflict countries (Lerch 2016) despite global trends towards denationalisation (Hansen 2012). In such contexts, governments typically see the added value of teaching the nation a "usable" (Wertsch 2002: 70) and "monumental" national past (Nietzsche 1997: 69) through textbooks disseminating an authoritative and uniform "closed national 'historical' narrative" (Nakou and Barca 2010: 8). This approach not only contravenes current historiographical and didactic trends; it also appears problematic, as a conciliatory strategy, if one considers that the public dominance of particular narratives in society has frequently been the object of grievances that have adversely factored into the conflict itself.

In divided societies emerging from violent conflict, the appeal to "consensus history", consisting in blending different views in a single 
narrative, risks degenerating into "hegemonic history" as a result of political hijacking. A new state-sanctioned and uncontested master-narrative or "official truth" may emerge, which is top-down, normative, expediently narrow and selective, homogenising and excluding or dismissive of alternative memories and narratives, and at odds with the historical record. In this narrative, difference and diversity are often glossed over or depicted as a menace to a precious unity to be safeguarded. While presented as embodying a nation's shared historical memory, single narratives are likely to reproduce existing power relations by endorsing the beliefs, values, norms and identity of dominant groups, thus possibly feeding new or renewed inequalities and societal rifts. In this sense, as Friedrich Nietzsche (1997) once warned us, "Sufficient danger remains should (specific narratives) grow too mighty and overpower the other modes regarding the past" (p. 75).

The experience in reforming history education in Rwanda represents a telling example of the pitfalls of the single-narrative approach to history textbook revision in contested post-conflict societies. In the early 1990s, the country experienced civil war and state-orchestrated genocide during which hundreds of thousands, primarily of the Tutsi minority, were killed by their Hutu neighbours. The violence ended with the military victory and political takeover by a Tutsi-dominated rebel movement. As part of a broader agenda of "national unity and reconciliation" and related memory politics, during the emergency moratorium phase launched in 1995, the post-genocide government worked towards revising purportedly divisive history curricula and textbooks. Recent research shows that, through revised history textbooks, the government has been enforcing a new, hegemonic narrative of past events, endorsing a narrow understanding of "legitimate knowledge" (Anyon 1978). This narrative promotes the concept of "Rwandanness", emphasising the nation's alleged primordial unity and dismissing ethnic identities as a historically unfounded colonial invention that was supposedly the primary cause of genocide in Rwanda. This official truth has been widely criticised by observers for forcibly repressing salient identities as well as related discussions on ongoing divisions in the present, while both underscoring Tutsi historical victimisation and silencing "Hutu memories" of suffering. This particular approach to history textbook revision, and to history politics in general, appears to rest on a quest for political legitimation and social control, effectively ensured in Rwanda through laws against "divisionism" and "genocide ideology", which have apparently coerced 
many into self-censorship while alienating a large part of the population (Bentrovato 2015; King 2014). Against this backdrop, developing and implementing alternative materials has proven largely unsuccessful. The constraints posed by strictly state-controlled contexts are illustrated by the experience of the US-based NGO Facing History and Ourselves in helping develop a collaborative history resource book for Rwandan secondary schools based on participatory methods. Eventually, the initiative was severely undermined by the withdrawal of local stakeholders' committed participation in the project due to widespread concerns connected to a political leadership that had grown increasingly intolerant of historical accounts diverging from the state-sanctioned "truth" (Freedman et al. 2008).

Post-Saddam Iraq is another case in point, which highlights the shortcomings of single-narrative textbooks that espouse a dominant or hegemonic rhetoric of illusive national unity when communal divisions and grievances remain unaddressed under increasingly authoritarian regimes. Textbooks produced in Iraq after the emergency phase and under the current Shi'i-dominant government have been disseminating a similarly homogenising nationalist single narrative, which clashes with realities on the ground. Through outright evasions that exceed the expediently selective approach adopted in Rwanda to study the country's history of violence, revised Iraqi textbooks elude references to sectarian fault lines by neglecting Shi'i and Sunni history altogether in order to preserve "the image of a unified Arab nation" (Rohde 2013a: 724). They further omit such divisive issues as the 2003 US-led military overthrow of the Sunni-dominated regime of Saddam Hussein and its aftermath, and the Kurdish question. This generally "unifying" narrative notwithstanding, observers have indicated the risks related to a creeping Shi'i bias in textbooks which could possibly estrange and disaffect nonShi'i groups (Ibid.: 725).

\section{The Promises of a Multinarrative and Multiperspective Approach: Narrative Plurality and Diversity}

Reflecting new trends in historiography and history didactics, the main alternative to the single-narrative approach to post-conflict textbook revision is the enquiry-based multinarrative and multiperspective approach, a model widely advocated since the 1990s as the "most effective way for history teaching to contribute to postconflict 
understanding" (McCully 2012: 146). Contrary to teaching a definite narrative, this approach, being grounded in the discipline of history, is centred on an interpretive and evidence-based process of historical enquiry, which regards all narratives as "provisional and open to question" (McCully 2012: 148; see also Seixas 2000; Stradling 2003). One common format for this particular model consists in source-based material presenting multiple narratives and perspectives for evaluation. An example of this approach is the "Joint History Project" supplementary teaching material for Southeast Europe (CDRSEE 2005). The material consists of four source-based workbooks that were jointly produced by a regional team of authors on the history of the Balkans. While the material excludes discussions on the particularly sensitive recent history, it occasionally addresses controversial topics by juxtaposing divergent historical interpretations in line with a multiperspective methodology (see also Fajfer 2013; Milosheva and Krushe 2010).

A different and uniquely creative example of the multinarrative and multiperspective approach is the "dual-narrative" methodology. This model finds its most renowned application in the non-governmental Israeli-Palestinian joint history textbook project "Learning Each Other's Historical Narrative". Launched in the midst of conflict, this binational resource, which, however, has not been officially approved for classroom use, juxtaposes two competing nationalist narratives of the conflictridden history of Israeli-Palestinian bilateral relations. These opposing narratives consist of accounts which authors from both sides mutually recognised as legitimate and which were cleansed of excessively offensive or emotive language upon the authors' dialogue and exchanges that marked the development stage of the material. The joint resource presents these narratives side by side on two columns of each page, separating them through a blank space designed to encourage pupils to develop their own understanding of the contested past. The intention underlying the project was for students to "become equipped to acknowledge, understand, and respect (without having to accept) the narrative of the other" (Adwan et al. 2012: x). This was seen as an "essential intermediate phase" in a context where "there is not enough common ground for Israelis and Palestinians to create a single historical narrative" (Bar-On and Adwan 2006: 310; see also Rohde 2012, 2013b). A similar multinarrative history textbook project was launched in India and Pakistan in 2013. Drawing on regular school history textbooks used in the two countries, this material puts their "different (often opposite) historical 
narratives side by side", covering key events in the tense history of Hindu-Muslim relations in this region (Daftuar 2013).

Arguably, by exposing pupils to narrative plurality and diversity regarding the past, this approach is deemed to be more democratic and to create opportunities for dialogue and rapprochement by encouraging pupils to question, critique and revisit exclusive and apparently irreconcilable group narratives and preconceived truths. The actual effects and impact of the internationally acclaimed multinarrative and multiperspective methodology on intergroup relations, however, remain empirically understudied, thus precluding definite conclusions as to its value and limitations. The implementation of this methodology faces a number of concerns, which relate to the complexities and challenges of teaching contested and conflictual narratives being laid bare in ethnographic studies in schools in several divided societies (e.g. Bekerman and Zembylas 2012). For example, while being presumably better suited for contested societies, the multinarrative and multiperspective approach has raised the concern that the permanent questioning it encourages may produce undesired uncertainty in fragile contexts and may thus be potentially more destabilising than supplying the nation with a definite and positive or progressive linear narrative of the shared past. It also raises the concern that, unless both teachers and pupils are effectively equipped with the tools and dispositions of the historical profession, this approach, by exposing differences and controversies, may further entrench polarisation rather than help communities transcend sectarian group narratives and encourage rapprochement. In relation to the Israeli-Palestinian project, in particular, critics have raised questions about the conciliatory value of a dual-narrative approach, which both confirms and "cements the bipolar structure of the conflict itself" by failing to take into account the diversity inherent within each society and related narratives (Rohde 2013a: 189).

\section{Beyond Content: The Transformative "Performative Dimension" of Post-conflict Textbook Work}

Research in post-conflict textbook writing, particularly regarding joint projects, suggests that, while such initiatives have been inevitably daunting and, in fact, often unsuccessful in effectively translating their outcomes into classroom practice, the processes involved have proved valuable in themselves. One of the most crucial, though less tangible, achievements identified in various case-studies from around the world is the attitudinal 
change induced by collaborative initiatives bringing together representatives from opposing conflict sides to produce textbooks or related guidelines (see case-studies in Korostelina and Lässig 2013). These observations serve as a fundamental starting point for reconsidering the conciliatory potential of post-conflict textbook revision from a processual perspective that may help further conceptualise the nexus between history textbooks and intergroup reconciliation. Upon this premise, this section moves beyond a discussion of history textbook designs and strategies that are the outcome of related activities in order to also include a reflection on the often overlooked yet significant "performative dimension" (Lässig 2013: 8 ) of post-conflict textbook work. Drawing on discourses on conflict and peacebuilding, this section argues the utility of a narrative-based approach to conflict transformation for a better understanding and assessment of the value of textbook projects. It uses this approach as a framework to conceptualise what can be termed a "transformative model of post-conflict textbook work". The contention underlying this model is that the conciliatory potential of textbook activities lies partly in the capacity of the processes of collaborative textbook development to encourage a process of "narrative transformation" of the competing accounts that typically accompany conflict - a process whose transformative dynamics and effects may further trickle down during the implementation phase in the classroom.

Theoretically grounded in social constructionism (Berger and Luckmann 1966), the framework from which the proposed model borrows places the reframing of conflict narratives and related "mythico-histories" (Malkki 1995) at the centre of conflict transformation processes geared towards instigating changes in intergroup perceptions and attitudes that are considered key to reconciliation (Austin et al. 2011; Kelman 2004; Kriesberg 2007; Lederach 1997). It regards narrative reexamination and reconfiguration as a critical step towards "un-sticking" conflict-relationships between opposing "mnemonic communities" that are often trapped within competing victimisation-based "schematic narrative templates" (Wertsch 1998: 60) through which they make sense of "reality". As Sara Cobb (2003) suggests, "Unless these stories are transformed or evolved, they retain their coherence, collecting 'data' that confirm the myths as events unfold". She further argues that "If there is to be an end to the cycle of violence, if there is to be an opening for building new relationships, [...] these myths must lose their totalitarian grip; they must be opened to new information, new plots, new character roles, and new themes" (p. 295; see also Cobb 2013; Mack 1990). 
This section argues that textbook revision and development processes are well positioned to undermine the coherence of competing conflict narratives warned against by Cobb. Specifically, textbook work appears to hold great potential for creating a "dialogical space" (Hermann 2004) in which to engage participants from former conflict sides in reassessing and redefining their narratives, and their underlying antagonistic perceptions and belief systems. This can be achieved through textbook work that involves and that facilitates sustained cooperative interaction and critical and "constructive confrontation with the painful past" (Nadler and Shnabel 2008: 44)—two processes otherwise respectively described in the conflict transformation literature as "instrumental" and "socioemotional" forms of "social learning" conducive to intergroup reconciliation (Aiken 2013; Nadler et al. 2008; Nadler and Shnabel 2008). By engaging former enemies in such processes of "social learning", textbook work may act as a catalyst for "narrative transformation" directed towards increased "narrative complexity" (Cobb 2003). It can, in other words, contribute towards broadening the narrow and uniform stock of stories that often define intergroup relations and towards crafting more complex and nuanced narratives on the basis of dialogical interaction and critical enquiry. The processes involved in this transformative model of textbook work may ultimately allow a transition from competing narratives that one-sidedly emphasise incompatible historical claims towards more inclusive and pluralistic narratives, which are at once shared and heteroglossic and which accept, expose and discuss multiple understandings of the divisive past on scientific bases while also being appreciative of the often overlooked positive interactions and transfers that marked histories of intergroup relations.

Based on worldwide experiences in post-conflict societies, a number of key procedural principles and prerequisites can be highlighted as being fundamental for this transformative process to occur within the proposed model of textbook work. The first regards the importance of adopting an inclusive, symmetrical, and democratic collaborative approach to textbook revision and development, which ensures a sense of empowerment and ownership for the various parties and sides involved. A review of case-studies on textbook projects indicates the importance of respecting a concern for inclusiveness and equality both in the configuration of participant groups and in the perspectives and stories discussed and eventually presented in the newly designed textbooks. This approach may both initiate and signal a crucial shift from a common practice 
whereby "legitimate knowledge" is determined by dominant groups towards more democratic practices, whereby history is co-authored by representatives of different groups, resulting in diverse voices in society being equally represented and heard in the textbooks. Failing to do so risks undermining the legitimacy and public perception of the impartiality of these projects and, more broadly, it risks perpetuating marginalisation and ultimately conflict. Past experience with unofficial textbook consultations in Northeast Asia, for instance, warns against the pitfalls of textbook activities that are based on asymmetrical communication. The one-sidedness that characterised these pioneering activities in the region, and which was manifest in their exclusive critique towards Japan as the only historical wrongdoer, undermined the initiative. It caused it to be perceived "as an appendage to the political debate" geared towards apology "rather than a driving force that could lend a new direction to the public discourse" (Pingel 2008: 196). This served as a clear lesson for later joint projects in Northeast Asia, which were markedly more considerate of the impediments to rapprochement posed by asymmetrical dialogue in textbook work (Han et al. 2012).

The proposed transformative model of post-conflict textbook work further presupposes a shift from a common practice of hiding conflict, controversies and diversity - be it behind utter silence or behind politically correct consensus - to acknowledging and openly confronting differences. Critical foundations for a meaningful and constructive dialogue on the shared but divisive past include the participants' basic acknowledgement of the both inevitable and legitimate existence of multiple and divergent perspectives and narratives on history. This acknowledgement entails the acceptance of the importance attached by each group to its ability to tell particular stories in which its identity is grounded. The model also necessitates the participants' willingness to respectfully engage with "conflicting views that fall within the range of reasonable disagreement", and this "without either endorsing them as clearly correct or rejecting them as clearly incorrect" (Gutmann and Thompson 2000: 22, 41).

The process of respectfully engaging with each other's narratives, including each other's painful experiences and sensitivities, further presupposes the participants' questioning of assumptions and preconceptions that may inhibit rational and constructive intergroup dialogue on the shared history. Inhibitors include assumptions of negative intentionality of "the other" (Cobb 1994) and assumptions of moral superiority 
and legitimate entitlement of the ingroup. The former are associated with practices of demonisation and dehumanisation of the perceived enemy typically accompanying violent conflict. Martha Nussbaum (1992) critically observes that, in conflict situations, "awareness of the enemy's similar humanity is easily lost from view” (p. 282), keeping groups trapped into dichotomous victim/perpetrator discourses that perpetuate cycles of violence and prevent rapprochement. The latter imply engaging in critical self-reflexivity, involving both awareness of ingroup suffering and an honest appraisal of the nature of ingroup actions and their supposed morality. This critical inward- and outward-looking process should be part of larger deconstructionist endeavours consisting in confronting and debunking respective myths, which, by their very nature, tend to hinder "narrative transformation" as mechanisms that "see[k] to establish the sole way of ordering the world and defining world-views" (Schöpflin 1997: 19).

These transformative processes are undoubtedly challenging to bring about, and can only be the result of long-term efforts. They may necessitate extensive and ongoing groundwork towards building mutual recognition and mutual trust, especially in the initial phase of the project, when opposing sides may hold rigid defensive and offensive positions. One should indeed foresee and intently address the challenges posed to these processes by the legacy of conflict and by related psychological barriers, with memories of violence and associated emotions often crippling intergroup receptive and empathic abilities that are fundamental to these projects. In the light of the inherent complexity and sensitivity of these endeavours, it may be beneficial, as has often been the case, for the dialogic processes that are at the core of such undertakings to be facilitated by a neutral third party in order to ensure "controlled communication" (Ellis 2006: 143) as part of an effort at "narrative mediation" (Winslade and Monk 2000). It may be equally beneficial for these processes to be grounded in exchanges of personal experiences and thus to aim at fostering basic personal relationships before moving to professional discussions.

Being geared towards mutual recognition of the experiences and painful legacy of each conflict side, the proposed approach to post-conflict textbook work ultimately holds significant potential towards contributing to an enhanced sense of justice that is widely considered key to reconciliation (Gibson 2004; Kriesberg 2004; Lederach 1997; Minow 1998). Particularly, it may contribute to victims' restored sense of dignity, which 
may have been undermined by denial or silence of experienced harm. Arguably, however, the most immediate value of this transformative model of post-conflict textbook work lies in its potential to build and empower a cooperative community of practice by acting as a forum for constructive intergroup engagement and collaboration directed towards a shared goal and vision. Experiences across the world, for instance in the Balkans, the Middle East and Northeast Asia, have illustrated the power of dialogical and cooperative textbook activities in prompting the participants' transformative shift from acting as representatives of a particular group to recasting themselves as "experts who acted independently from a political agenda" (Pingel 2008: 193). Joint ventures of this kind can act as evidence of the possibility of rapprochement and cooperation and can thus build trust in a shared peaceful and democratic future where differences can be accepted and embraced rather than suppressed and silenced. Ideally, these same processes and experiences, if echoed in the classroom, can lend such projects a multiplier or ripple effect. In the long term, they may impact younger generations' knowledge and attitudes and may, through young people, stimulate transformation within families and communities, eventually laying the foundation for a new social contract that is grounded on respect for pluralism, democracy and human rights.

\section{Actors and Interactions in Post-conflict Textbook Work}

In keeping with a processual perspective on post-conflict textbook work, an important factor to be considered when analysing and assessing these activities relates to the interplay between grassroots, national and international actors, and to the nature and level of interaction and intersection between top-down and bottom-up processes and initiatives. Post-conflict textbook work ought to be understood as a multi-actor and multilevel process, involving a variety of stakeholders, including state actors and agencies, international organisations, NGOs and academic institutions. It is equally understood as an interdisciplinary field which, as declared by UNESCO (1949), "must involve the closest cooperation of scholars, educators, and psychologists, who understand the implications of materials presented to pupils" (p. 60). As Stuart Foster (2011) observes, it is also "a transnational field, resulting from co-operation, competition and transfers" (p. 33).

When it comes to textbook activities, governments and their agencies, notably national ministries of education, are undoubtedly key 
actors, whose political endorsement has proven essential for these initiatives' legitimacy and practical implementation. Research on official textbook commissions in post-WWII Europe has indicated that their viability and perceived success largely stemmed from their institutional backing by the respective governments. Conversely, abundant research points to lack of political support and commitment as a recurring disabling factor. Numerous cases have been reported of innovative materials having been banned, boycotted or withdrawn by governments upon damning reaction by powerful spoiler-groups, who time and again have slandered and even threatened their authors for supposedly betraying the ingroup. This has been the unfortunate fate of many initiatives by civil society groups, which, in post-conflict contexts, have often taken the lead in conciliatory textbook work, but whose power has been regularly undermined by highly centralised education systems. With many (post-conflict) countries being characterised by strictly state-controlled textbook screening and authorisation processes, any failure to secure official approval almost inevitably implies the books' absence from the classrooms. That being said, state involvement is also potentially problematic as it may translate into political compromise and lead to these activities being less likely to critically address highly controversial issues.

With these projects having to rely on substantial funding, worldwide experience has shown international actors as being highly instrumental in supporting both official and unofficial textbook work in post-conflict societies. Some of them, notably the Council of Europe and UNESCO, have a proven record of active and influential involvement in this field. Historically, these organisations have been the drivers of conciliatory textbook work, sponsoring history textbook dialogue and cooperation, and the production of recommendations and guidelines for textbook authors (e.g. CoE 2001, 2009; Minkina-Milko 2012; Pingel 2010; Stobart 1999). Throughout the decades, an expanding network of international actors have provided funding and expertise and have played a consultative, coordinating, supervising and/or mediating role-visibly resulting in the diffusion of certain dominant concepts and models, such as multiculturalism and multiperspectivity. They have been involved in the design, development, production and distribution of new teaching materials as well as in local stakeholders' professional training in related activities. Their level of influence in setting agenda, goals and outcomes has thereby varied and has been the greatest in contexts characterised by institutional weakness and aid dependency. As hinted at earlier in 
relation to highly interventionist emergency textbook activities, ensuring local ownership of related processes and outcomes remains a challenge in which failure has risked undermining the legitimacy and credibility of these projects, feeding popular perceptions of outside imposition of foreign models.

\section{Contextual Constraints and Possibilities of Conciliatory Textbook Work}

Evidently, post-conflict textbook work is a hard task which, more often than not, has faced formidable challenges and constraints, especially of a political nature. As worldwide experiences indicate, at all levels from conception to implementation, perseverance and risk-taking have marked these initiatives. The inclusive, balanced and complex narratives and texts that are the ideal product of conciliatory textbook work typically represent counter-discourses and are therefore commonly resisted. Time and again, they have been the object of fierce public debates, political dispute and protest, which have regularly proven fatal to these projects.

As a general rule, the most successful initiatives, notably those officially approved, could only be realised after years, if not decades, of dialogue, debate and negotiation. For instance, it took the German-Polish textbook commission over a decade to negotiate and gain formal acceptance of its bilateral recommendations. Similarly, the joint guidelines for textbook authors that were developed by an expert commission in Bosnia in line with a multinarrative and multiperspective model underwent protracted negotiations before being officially endorsed (Pingel 2008: 193, this volume). Several other conciliatory initiatives have been short-lived or never reached fruition, often as a result of vehement criticism from powerful conservative groups. In Croatia, for example, a temporary textbook supplement produced in 2005, which acknowledged Croat crimes perpetrated against Serbs during the conflict in the early 1990s, was swiftly withdrawn following public protests on account of its supposedly "'sacrificing' the sufferings of Croats in the war for the sake of reconciliation" (De Baets 2015: 11). The initiative, however, prepared the groundwork for later textbook work, which resulted in new textbooks adopting a comparatively balanced approach to the conflict-ridden past (Koren and Baranovic 2009). In some contexts, compromise, possibly induced by a desire to accommodate political and/or societal sensitivities, led to evasion and/or political correctness coming at the expense of historical accuracy in new textbooks dealing with the divisive past. In 
Cambodia, for example, the first state-approved history textbook covering Khmer Rouge history, which was produced by a local NGO (Dy 2007) and was recently endorsed by the ministry of education to teach younger generations about the genocide that marked Cambodia in the 1970 s, circumvents several sensitive questions of responsibility in a context where a number of former members of the Khmer Rouge presently occupy prominent positions in government (De Baets 2015: 14). In Guatemala, accuracy is similarly compromised in new social studies textbooks in a context where silence on the recent violent past is, however, maintained in official curricula. Adopting a predominant human rights perspective, current textbooks present a superficial narrative of the conflict which evades discussions on historical agency as they point the finger at the abstract concept of "culture of violence" as the cause of the country's decades-long civil war (Bellino 2014; Oglesby 2007).

Conciliatory textbook work that did succeed in coming to fruition has frequently faced further serious challenges related to the implementation of its products and their translation into classroom practice. This is again particularly true for unofficial supplementary material, whose use, being left to teachers' discretion, has proven to be limited across the board. Described by Simone Lässig (2013) as "probably the most important translators (or obstructers) of reform ideas" (p. 14), teachers, upon whom the multiplier effect of conciliatory textbook work in the classroom largely depends, have been found to resist and subvert innovative textbook content. Especially in "hot spots", as found in, for instance, Northern Ireland (Kitson 2007) and Israel (Gordon 2005), educators have often pre-emptively avoided or abandoned material addressing sensitive and controversial historical issues related to intergroup conflict. They have done so out of fear of opening fresh wounds in the classroom, of receiving angry reactions by pupils or their parents and, ultimately, for safety reasons (Bentrovato 2016). A shift away from adverse or safe pedagogical practices necessarily requires specific teacher training. It requires training encompassing not only attention to new content knowledge and teaching methods, but also to offering opportunities for history educators to deal with their own painful experiences and memories of conflict, to question their own preconceptions and bias, and to learn how to responsibly and constructively deal with conflict and discomfort that may arise in the classroom upon discussing controversial perspectives prompted by textbook use. From a more practical perspective, the meaningful use of multiperspective materials by teachers may be constrained 
by curriculum content overload and knowledge-based examination, and by limited access to these materials in typically resource-poor post-conflict settings.

Naturally, possibilities and constraints of post-conflict history textbook work are determined by the specific context and circumstances, which inevitably influence the processes, outcome and impact of such initiatives. A variety of enabling or disabling contextual conditions may affect textbook work and its conciliatory potential. These include, inter alia: the nature of the conflict, including its more or less extensive scope and length and related levels of collective trauma, as well as its temporal proximity; its stage and outcome, namely whether the conflict has been settled, notably through one-sided military victory or through negotiated agreement resulting from military stalemate and combat fatigue, or, again, whether the conflict is still openly or latently ongoing; the TJ path chosen to deal with the past, be it one focused on amnesia, truthtelling and/or criminal accountability; the larger political system, including the level of symmetry in power relations between (former) parties to the conflict; and the degree of foreign involvement in the conflict settlement and its aftermath as well as the strength of civil society. Whereas the distinct effects of different scenarios yet remain to be systematically investigated, what is evident is the defining role of the general political climate in which these projects are embedded, the latter having proven to be closely tied to political contingencies.

Worldwide experience in history textbook revision points to a number of contextual conditions in which these activities are more likely to have a conciliatory and transformative effect on intergroup relations. Existing case-studies suggest the favourability of a political environment marked by relative stability and by a broader policy of rapprochement. A good example of such a case is the German-Polish textbook project, which was enabled by the specific historical-political context of detente inaugurated by Willy Brandt's German Ostpolitik (Lässig and Strobel 2013). Conversely, ongoing (or renewed) violence and injustice and the absence of a larger conciliatory context may cause similar endeavours to become hostage to political caprice and may additionally lessen the population's receptiveness to the initiatives. The PRIME project in Israel/Palestine illustrates well the high probability of unresolved tensions and renewed violence causing collaborative textbook projects to reach a deadlock and to be viewed with suspicion and be rejected both by politicians and by teachers, pupils and society at large across the divide (Eid 2010; Rohde 
2013a). The case of post-genocide Rwanda further demonstrates that peace and stability are not sufficient elements for a favourable context for conciliatory textbook work. A democratic political environment, where textbook work can rely on open and unrestricted public and scholarly debate, is equally crucial for new educational materials not to convey a highly problematic "hegemonic history". Furthermore, experiences around the world, for instance in the self-proclaimed Turkish Republic of Northern Cyprus, point to the constraints exercised on conciliatory textbook work by the political contingency of regime change, notably the coming to power of conservative parties. In the case of Northern Cyprus, political change marked a return to ethno-nationalist history textbooks after a short-lived introduction of more conciliatory materials that had been promoting a sense of common identity (Evripidou 2010). Another significant factor affecting these initiatives relates to the nature of broader educational policies and structures in which they are embedded, specifically the extent to which these policies are conducive to intergroup integration or segregation. In Bosnia, Cyprus, Israel/ Palestine and Lebanon, for instance, where formal history curriculum and textbook revision has been (tentatively) undertaken in the wake of peace processes, such educational policies and structures appear to have severely undermined efforts to harmonise history teaching and reconcile conflicting narratives through textbooks. Here, sectarianism continues to be pervasive within the context of highly segregated education systems, pointing to the obstinacy of competing group narratives in such contexts (Nasser and Nasser 2008; Torsti 2009; Van Ommering 2015; Zembylas 2013).

If it is true that the existence of supportive institutional structures, and particularly of institutional rapprochement, is likely to provide a favourable context for conciliatory textbook revision, formal TJ processes may lend unique opportunities for this purpose. As highlighted by emerging research advocating for crafting stronger connections between the fields of education and TJ (Cole 2007; Ramírez-Barat and Duthie 2015), there is considerable value in seeing post-conflict textbook revision anchored in a TJ framework, particularly so within the context of the work of official truth (and reconciliation) commissions (TRCs). As part of their mandate, truth commissions are expected to produce a public record of historical injustice and abuse, including their causes, scope, dynamics and consequences, through investigation that typically relies on statement-taking from victims, perpetrators and witnesses (Hayner 2002). 
Their prominent work in dealing with the recent violent past is still limitedly exploited as an opportunity to support history education reform and textbook revision. Their work may provide an institutional framework for the re-examination of textbooks as part of an investigation into the role of the education sector in contributing to conflict while also dispensing source material for new textbooks deriving from their broader investigative work on the conflict as outlined in their final reports. This, however, should be considered with the understanding that the record produced by such entities is neither complete nor definitive, but rather is a selective representation of the violent past (Hayner 2002; Imbleau 2004). Hitherto, only timid and largely unsuccessful attempts have been made to integrate TRC findings into mainly supplementary educational materials, most notably in Guatemala, Peru and Sierra Leone. In Guatemala and Peru, these attempts were called to a halt by the government (Paulson 2010, 2015), while in Sierra Leone, TRC-related school materials appear to have fallen into oblivion mainly as a result of lack of government follow-up towards including these resources into what largely remains an outdated and evasive official curriculum (Bentrovato 2017).

\section{Conclusion}

This chapter is based on the premise that history textbooks are significant means that can either support or hinder reconciliation in the context of intergroup conflict. On that basis, it analysed history textbook revision and development as one component of broader peacebuilding and reconciliation efforts in societies emerging from violent conflict. The chapter surveyed some of the key approaches to post-conflict textbook work and their related narrative strategies as they have been employed in countries across the globe. In reviewing current practices and emerging trends in this field, it pointed to a number of pitfalls and opportunities having marked these endeavours. In relation to the narrative strategies adopted in textbook activities in both the shorter and longer term, this chapter questioned the rationale and the possible implications of different responses to the common challenge of dealing with societal conflict, diversity and controversy in history textbooks. In particular, it questioned the value of post-conflict models of textbook work that espouse either narrative evasion or elision, or single-narrative approaches. Its review of worldwide experiences suggests that these strategies, while ostensibly 
conciliatory in divided societies, are unlikely to be conducive to improved intergroup relations as they both preclude a chance for younger generations to make sense of a complex and contentious violent past and to transcend competing group narratives that hinder historical understanding. They may in fact counter intergroup reconciliation efforts, reinforcing sectarian divisions by leaving young people at the mercy of narrow and partisan family and community narratives that may openly or covertly circulate in society. While it acknowledges existing concerns related to the possible destabilising effects of less evasive and more complex narratives, this chapter argues for the comparative value of alternative multinarrative and multiperspective textbook designs. It thereby agrees with other scholars' contentions regarding the particular value of teaching contested history "as a 'mosaic of intercommunicating stories and memories', which transcend communalist and nationalist boundaries while acknowledging their existence" (Rohde 2013a: 189-190, citing Naveh 2006). That being said, this chapter is cautious not to overestimate the overall significance of textbooks within educational settings. It acknowledges textbooks as being only one among the multiple resources directing an effective enquiry-based and multiperspective approach to history education. Concomitantly, it recognises the critical role of teachers, who, even in the most unfavourable circumstances, could turn a biased textbook into a great resource for a transformative lesson. ${ }^{2}$

Having taken stock of some of the popular approaches and designs characterising current practices in post-conflict history textbook work, this chapter highlighted the less tangible value potentially inherent in collaborative processes of textbook revision and development, arguing for the benefit for this intrinsic potential to be capitalised upon and to be explicitly considered in the conception, implementation and evaluation of such initiatives. On that premise, it proposed a transformative model of post-conflict history textbook work, presenting this as a potential catalyst for instrumental and socioemotional reconciliation entailing the participants' challenging and transforming antagonistic narratives and underlying belief systems through sustained dialogical and cooperative interaction and constructive confrontation with the past. Built around the concept of dialogical "narrative transformation", the suggested model of post-conflict textbook work is proposed as having the potential to foster intergroup reconciliation by creating opportunities towards promoting former enemies' (re)humanisation, reciprocal empathy and acknowledgement of respective past suffering and common ground, and 
their envisioning of a shared future. In recognition of the complexity and contingency of these undertakings, the chapter further draws attention to the actors and contextual factors and conditions that may either hinder or enable history textbook revision playing a conciliatory role in divided societies. This potential is thereby held to be especially dependent upon these activities taking place within a favourable political and social environment and upon their being anchored in a broader institutional framework of rapprochement as an integral part of holistic efforts aimed at addressing the violent past and its legacies.

While this chapter seeks to make a contribution to further mapping and conceptualising the field of post-conflict history textbook revision and development, it also calls for a continued need for in-depth analysis and sophisticated frameworks of evaluation to examine and capitalise upon the conciliatory and transformative potential of such projects. Particularly, more empirical research is needed to assess the processes and dynamics involved, the societal reception of the material by its targeted audiences, and the effects and impact of textbook activities on intergroup relations in their different forms and in different contexts. These undoubtedly are fundamental, yet complex, emerging questions, the answers to which will help us chart the way forward.

\section{Notes}

1. Notable exceptions to this particular trend are cases in post-revolutionary contexts, where far-reaching textbook changes may have been introduced in the immediate aftermath of political overhaul, provided sufficient resources are available to do so. The author is thankful for Falk Pingel's observation that in the cases of post-war Germany and Japan, for instance, the most innovative textbooks and curricula were produced immediately after WWII under American occupation, whereas more conservative textbooks appeared after the occupation.

2. The author is grateful to Alan McCully for stressing this important point.

\section{REFERENCES}

Adwan, S., Bar-On, D., \& Naveh, E. (Eds.). (2012). Side by side: Parallel histories of Israel-Palestine. New York: New Press.

Ahonen, S. (2013). Postconflict history education in Finland, South Africa and Bosnia-Herzegovina. Nordidactica: Journal of Humanities and Social Science Education, 1, 90-103. 
Aiken, N. T. (2013). Identity, reconciliation and transitional justice: Overcoming intractability in divided societies. New York: Routledge.

Al-Tikriti, N. (2010). War, state collapse and the predicament of education in Iraq. In A. E. Mazawi \& R. G. Sultana (Eds.), Education and the Arab "world": Political projects, struggles, and geometries of power (pp. 350-360). London: Routledge.

Anderson, B. (1991). Imagined communities: Reflections on the origin and spread of nationalism (Rev ed.). London: Verso.

Anyon, J. (1978). Elementary social studies textbooks and legitimate knowledge. Theory and Research in Social Education, 6, 40-55.

Apple, M. W. (1993). Official knowledge: Democratic education in a conservative age. London: Routledge.

Apple, M. W., \& Christian-Smith, L. K. (Eds.). (1991). The politics of the textbook. New York: Routledge.

Austin, B., Fischer, M., \& Giessmann, H. J. (Eds.). (2011). Advancing conflict transformation. The Bergh of handbook II. Opladen/Farmington Hills: Barbara Budrich Publishers.

Bar-On, D., \& Adwan, S. (2006). The PRIME shared history project: Peacebuilding project under fire. In Y. Iram, H. Wahrman, \& Z. Gross (Eds.), Educating toward a culture of peace (pp. 309-323). Charlotte, NC: Information Age Publishing.

Bar-Tal, D. (2000). From intractable conflict through conflict resolution to reconciliation: Psychological analysis. Political Psychology, 21(2), 351-365.

Bar-Tal, D. (2003). Collective memory of physical violence: Its contribution to the culture of violence. In E. Cairns \& M. D. Roe (Eds.), The role of memory in ethnic conflict (pp. 77-93). Houndmills, UK: Palgrave Macmillan.

Bar-Tal, D., \& Bennink, G. H. (2004). The nature of reconciliation as an outcome and as a process. In Y. Bar-Siman-Tov (Ed.), From conflict resolution to reconciliation (pp. 11-38). Oxford: Oxford University Press.

Barton, K. C., \& McCully, A. W. (2005). History, identity and the school curriculum in Northern Ireland: An empirical study of secondary students' ideas and perspectives. Journal of Curriculum Studies, 37(1), 85-116.

Bekerman, Z., \& Zembylas, M. (2012). Teaching contested narratives: Identity, memory and reconciliation in peace education and beyond. Cambridge: Cambridge University Press.

Bellino, M. J. (2014). Whose past, whose present? Historical memory among the "postwar" generation in Guatemala. In J. H. Williams (Ed.), (Re) constructing memory: School textbooks and the imagination of the nation (pp. 131-153). Rotterdam: Sense Publishers.

Bentrovato, D. (2015). Narrating and teaching the nation: The politics of education in pre-and post-genocide Rwanda. Göttingen: V\&R Unipress. 
Bentrovato, D. (2016). Whose past, what future? Teaching contested histories in contemporary Rwanda and Burundi. In D. Bentrovato, K. V. Korostelina, \& M. Schulze (Eds.), History can bite: History education in divided and postwar societies (pp. 221-242). Göttingen: V\&R Unipress.

Bentrovato, D. (2017). Beyond transitional justice: Evaluating school outreach programmes and educational materials in post-war Rwanda and Sierra Leone. In C. Ramírez-Barat \& M. Schulze (Eds.), Transitional Justice and Education: Engaging Children and Youth in Justice and Peacebuilding through Educational Media, Curricula and Outreach. Göttingen: V\&R Unipress.

Bentrovato, D., Korostelina, K. V., \& Schulze, M. (Eds.). (2016). History can bite: History education in divided and postwar societies. Göttingen: V\&R Unipress.

Buckley-Zistel, S., Koloma Beck, T., Braun, C., \& Mieth, F. (Eds.). (2014). Transitional justice theories. Abington: Routledge.

Burde, D. (2014). Schools for conflict or for peace in Afghanistan. New York: Columbia University Press.

Berger, P., \& Luckmann, T. (1966). The social construction of reality: A treatise in the sociology of knowledge. New York: Anchor Books.

Cairns, E., \& Roe, M. D. (Eds.). (2003). The role of memory in ethnic conflict. New York: Palgrave.

Carretero, M. (2011). Constructing patriotism: Teaching history and memories in global worlds. Charlotte, NC: Information Age Publishing.

CDRSEE. (2005). Teaching modern Southeast European history. Alternative educational materials (Vol. 1-4). Thessaloniki: Center for Democracy and Reconciliation in Southeast Europe.

Clark, P., \& Palmer, N. (2012). Challenging transitional justice. In N. Palmer, P. Clark, \& D. Granville (Eds.), Critical perspectives in transitional justice (pp. 1-16). Antwerp: Intersentia.

Cobb, S. (1994). "Theories of responsibility": The social construction of intentions in mediation. Discourse Processes, 18(2), 165-186.

Cobb, S. (2003). Fostering coexistence in identity-based conflicts: Towards a narrative approach. In A. Chayes \& M. Minow (Eds.), Imagine coexistence (pp. 294-310). San Francisco: Jossey Bass.

Cobb, S. (2013). Speaking of violence: The politics and poetics of narrative in conflict resolution. New York: Oxford University Press.

CoE (Council of Europe). (2001). Recommendation Rec(2001)15 on history teaching in twenty-first-century Europe. Retrieved July, 3, 2017, from https:// rm.coe.int/ $16805 \mathrm{e} 2 \mathrm{c} 31$.

CoE (Council of Europe). (2009). Recommendation 1880 (2009)1 history teaching in conflict and post-conflict. Retrieved July, 3, 2017, from http://assembly. coe.int/nw/xml/XRef/Xref-XML2HTML-en.asp?fileid=17765\&lang=en.

Cole, E. A. (2007). Transitional justice and the reform of history education. International Journal of Transitional Justice, 1, 115-137. 
Daftuar, S. (2013, September 16). One story, two sides. The Hindu. Retrieved July, 3, 2017, from http://www.thehindu.com/features/magazine/onestory-two-sides/article5124147.ece.

Daher, M. (2012). On the impossibility of teaching history in Lebanon: Notes on a textbook controversy. In S. Alayan, A. Rohde, \& S. Dhouib (Eds.), The politics of education reform in the Middle East. Self and other in textbooks and curricula (pp. 97-111). New York: Berghahn Books.

Danieli, Y. (Ed.). (1998). International handbook of multigenerational legacies of trauma. New York: Plenum Press.

De Baets, A. (2015). Post-conflict history education moratoria: A balance. World Studies in Education, 16(1), 5-30.

Defrance, C., \& Pfeil, U. (2013). Symbol or reality? The background, implementation and development of the Franco-German history textbook. In K. Korostelina \& S. Lässig (Eds.), History education and postconflict reconciliation: Reconsidering joint textbook projects (pp. 52-68). London: Routledge.

Dimou, A. (Ed.). (2009). "Transition" and the politics of history education on Southeast Europe. Göttingen: V\&R Unipress.

Dy, K. (2007). A history of democratic Kampuchea 1975-1979. Phnom Penh: Documentation Center of Cambodia.

Dy, K. (2008). Teaching genocide in Cambodia: Challenges, analysis, and recommendations. Retrieved July, 3, 2017, from http://d.dccam.org/Projects/ Genocide/Boly_Teaching_Genocide_in_Cambodial.pdf.

Dy, K. (2013). Challenges of teaching genocide in Cambodian secondary school. Policy and Practice: Pedagogy about Holocaust and Genocide Papers. Paper 4. Retrieved July, 3, 2017, from http://commons.clarku.edu/pedagogy $2013 / 4$.

Duncan, D. (2011). Education in Libya after Gaddafi. Retrieved July, 3, 2017 from http://www.pri.org/stories/2011-11-11/education-libya-after-gaddafi.

Eid, N. (2010). The inner conflict: How Palestinian students in Israel react to the dual narrative approach concerning the events of 1948. Journal of Educational Media, Memory, and Society, 2(1), 55-77.

Ellis, D. G. (2006). Transforming conflict: Communication and ethnopolitical conflict. Lanham, MD: Rowman \& Littlefield.

Evripidou, S. (2010). Taking a step back in the history books in the North. Cyprus Mail, 5 March.

EUROCLIO. (2008). Ordinary people in an extraordinary country. Everyday life in Bosnia and Herzegovina, Croatia and Serbia between East and West 19451990. The Hague: EUROCLIO.

EUROMID (Resource Centre on Euro-Middle East Affairs). (2006). The role of textbooks in the Middle East conflict. Retrieved July, 3, 2017, from http://www. europarl.europa.eu/meetdocs/2004_2009/documents/fd/il20062006_05/ il20062006_05en.pdf. 
Fajfer, L. (2013). Reconnecting history: The joint history project in the Balkans. In K. Korostelina \& S. Lässig (Eds.), History education and postconflict reconciliation: Reconsidering joint textbook projects (pp. 140-154). London: Routledge.

Foster, S. J. (2011). Traditions in international textbook research and revision. Education Inquiry, 2(1), 5-20.

Foster, S. J., \& Crawford, K. A. (Eds.). (2006). What shall we tell the children? International perspectives on school history textbooks. Charlotte, NC: Information Age Publishing.

Freedman, S. W., Weinstein, H. M., Murphy, K., \& Longman, T. (2008). Teaching history after identity-based conflicts: The Rwanda experience. Comparative Education Review, 52(4), 663-690.

GCPEA (Global Coalition to Protect Education from Attack). (2014). Education under attack, 2014. New York: GCPEA.

Gibson, J. L. (2004). Overcoming apartheid: Can truth reconcile a divided nation?. New York: Russel Sage Foundation.

Gordon, D. (2005). History textbooks, narratives, and democracy: A response to Majid Al-Haj. Curriculum Inquiry, 35(3), 367-376.

Gutmann, A., \& Thompson, D. (2000). The moral foundations of truth commissions. In R. Rotberg \& D. Thompson (Eds.), Truth V. Justice: The morality of truth commission (pp. 22-44). Princeton: Princeton University Press.

Hamber, B. (2009). Transforming societies after political violence: Truth, reconciliation, and mental health. New York: Springer.

Han, U., Kondo, T., Yang, B., \& Pingel, F. (2012). History education and reconciliation: Comparative perspectives on East Asia. Frankfurt am Main: Peter Lang.

Hansen, J. M. (2012). De-nationalize history and what have we done? Ontology, essentialism, and the search for a cosmopolitan alternative. In M. Carretero, M. Asensio, \& M. Rodriguez-Moneo (Eds.), History education and the construction of national identities (pp. 17-32). Charlotte, NC: Information Age Publishing.

Hayner, P. B. (2002). Unspeakable truths: Facing the challenge of truth commissions. New York: Routledge.

Hermann, T. (2004). Reconciliation: Reflections on the theoretical and practical utility of the term. In Y. Bar-Siman-Tov (Ed.), From conflict resolution to reconciliation (pp. 39-60). Oxford: Oxford University Press.

Imbleau, M. (2004). Initial truth establishment by transitional bodies and the fight against denial. In W. Schabas \& S. Darcy (Eds.), Truth commissions and courts: The tension between criminal justice and the search for the truth (pp. 159-192). New York: Kluwer Academic.

INEE (Inter-Agency Network for Education in Emergencies). (2010). Guidance notes on teaching and learning. New York: INEE.

Kelman, H. C. (2004). Reconciliation as identity change: A social psychological perspective. In Y. Bar-Siman-Tov (Ed.), From conflict resolution to reconciliation (pp. 111-124). Oxford: Oxford University Press. 
King, E. (2014). From classrooms to conflict in Rwanda. New York: Cambridge University Press.

Kitson, A. (2007). History teaching and reconciliation in Northern Ireland. In E. A. Cole (Ed.), Teaching the violent past: History education and reconciliation (pp. 123-155). Lanham, MD: Rowman \& Littlefield.

Koren, S., \& Baranović, B. (2009). What kind of history education do we have after eighteen years of democracy in Croatia? Transition, intervention and history education politics (1990-2008). In A. Dimou (Ed.), “Transition” and the politics of history education in Southeastern Europe (pp. 91-140). Göttingen: V\&E Unipress.

Korostelina, K., \& Lässig, S. (Eds.). (2013). History education and postconflict reconciliation: Reconsidering joint textbook projects. Abingdon, UK: Routledge.

Kriener, J. (2012). Different layers of identity in Lebanese textbooks. In S. Alayan, A. Rohde, \& S. Dhouib (Eds.), The politics of education reform in the Middle East: Self and other in textbooks and curricula (pp. 131-153). New York: Berghahn Books.

Kriesberg, L. (2004). Comparing reconciliation actions within and between countries. In Y. Bar-Siman-Tov (Ed.), From conflict resolution to reconciliation (pp. 81-110). Oxford: Oxford University Press.

Kriesberg, L. (2007). Reconciliation: Aspects, growth, and sequences. International Journal of Peace Studies, 12, 1-21.

Lässig, S. (2013). Introduction: Post-conflict reconciliation and joint history textbook projects. In K. Korostelina \& S. Lässig (Eds.), History education and postconflict reconciliation: Reconsidering joint textbook projects (pp. 1-18). Abingdon, UK: Routledge.

Lässig, S., \& Strobel, T. (2013). Towards a joint German-Polish history textbook: Historical roots, structures and challenges. In K. Korostelina \& S. Lässig (Eds.), History education and postconflict reconciliation: Reconsidering joint textbook projects (pp. 90-119). Abingdon, UK: Routledge.

Leach, F., \& Dunne, M. (Eds.). (2007). Education, conflict and reconciliation: International perspectives. Bern: Peter Lang.

Lederach, J. P. (1997). Building peace: Sustainable reconciliation in divided societies. Washington, DC: United States Institute of Peace Press.

Lederach, J. P. (2001). Civil society and reconciliation. In C. A. Crocker, F. O. Hampson, \& P. Aall (Eds.), Turbulent peace: The challenges of managing international conflict (pp. 841-854). Washington, DC: USIP.

Lee, S. Y., \& Özerdem, A. (Eds.). (2015). Local ownership in international peacebuilding: Key theoretical and practical issues. Abingdon, UK: Routledge.

Lerch, J. (2016). Embracing diversity? Textbook narratives in countries with a legacy of internal armed conflict (1950 to 2011). In D. Bentrovato, K. V. Korostelina, \& M. Schulze (Eds.), History can bite: history education in divided and postwar societies. Göttingen: V\&R Unipress. 
Mack, J. E. (1990). The psychodynamics of victimisation among national groups in conflict. In V. Volkan, D. A. Julius, \& J. V. Montville (Eds.), The psychodynamics of interpersonal relationships (pp. 119-129). Lexington, MA: Lexington Books.

Malkki, L. H. (1995). Purity and exile: Violence, memory, and national cosmology among Hutu refugees in Tanzania. Chicago: University of Chicago Press.

Marsden, W. E. (2001). The school textbook: Geography, history and social studies. London: Routledge.

McCully, A. W. (2012). History teaching, conflict and the legacy of the past. Education, Citizenship and Social Justice, 7(2), 145-159.

Milosheva, M., \& Krushe, D. (2010). Out of the broken mirror: Learning for reconciliation through multi-perspective history teaching in Southeast Europe. n.p.: USAID.

Minkina-Milko, T. (2012). Teaching and learning history for strengthening reconciliation and the peace-building process: Experience of the council of Europe. In M. Shuayb (Ed.), Rethinking education for social cobesion: International case studies (pp. 232-243). Basingstoke, UK: Palgrave Macmillan.

Minow, M. (1998). Between vengeance and forgiveness: Facing history after genocide and mass violence. Boston: Beacon Press.

Mueller-Sainy, G. (Ed.). (2011). Designing history in East Asian textbooks: Identity politics and transnational aspirations. New York: Routledge.

Nadler, A., Malloy, T., \& Fisher, J. D. (2008). Intergroup reconciliation: Dimensions and themes. In A. Nadler, T. Malloy, \& J. D. Fisher (Eds.), The social psychology of intergroup reconciliation (pp. 3-12). Oxford: Oxford University Press.

Nadler, A., \& Shnabel, N. (2008). Instrumental and socioemotional paths to intergroup reconciliation and the needs-based model of socioemotional reconciliation. In A. Nadler, T. Malloy, \& J. D. Fisher (Eds.), The social psychology of intergroup reconciliation (pp. 37-56). Oxford: Oxford University Press.

Nakou, I., \& Barca, I. (Eds.) (2010). Contemporary public debates over history education. In International review of history education series. Charlotte, NC: Information Age Publishing.

Nasser, R., \& Nasser, I. (2008). Textbooks as a vehicle for segregation and domination: State efforts to shape Palestinian Israelis' identities as citizens. Journal of Curriculum Studies, 40(5), 627-650.

Naveh, E. (2006). The dynamics of identity construction in Israel through education. In R. I. Rotberg (Ed.), Israeli and Palestinian narratives of conflict: History's double belix (pp. 244-270). Bloomington: Indiana University Press.

Nicholls, J. (2006). School history textbooks across cultures: International debates and perspectives. Oxford: Symposium Books.

Nietzsche, F. (1997). Untimely meditations. D. Breazeale (Ed.), trans. R. J. Hollingdale. Cambridge: Cambridge University Press. 
Nussbaum, M. C. (1992). Tragedy and self-sufficiency. Plato and Aristotle on fear and pity. In A. O. Rorty (Ed.), Essays on Aristotle's poetics (pp. 261-290). Princeton: Princeton University Press.

Oberschall, A. (2007). Conflict and peace building in divided societies. Responses to ethnic violence. New York: Routledge.

Oglesby, E. (2007). Historical memory and the limits of peace education: Examining Guatemala's memory of silence and the politics of curriculum design. In E. A. Cole (Ed.), Teaching the violent past: History education and reconciliation (pp. 175-205). Lanham, MD: Rowman \& Littlefield.

Ondek Laurence, P. (1993). The reading of silence: Virginia Woolf in the English tradition. Stanford: Stanford University Press.

Paulmann, J. (1998). Internationaler Vergleich und interkultureller Transfer. Zwei Forschungsansäntze zur eurpäischen Geschichtedes 18. bis 20 Jahrhunderts (International comparison and intercultural transfer. Two research approaches to European history of the 18th until the 20th centuries). Historische Zeitschrift, $3,649-685$.

Paulson, J. (2010). Truth commissions and national curricula: The case of recordandonos in Peru. In S. Parmar, M. J. Roseman, S. Siegrist, \& T. Sowa (Eds.), Children and transitional justice: Truth telling, accountability and reconciliation (pp. 327-364). Cambridge, MA: Harvard University Press.

Paulson, J. (2015). "Whether and how?" History education about recent and ongoing conflict: A review of research. Journal on Education in Emergencies, $1(1), 14-47$.

Pingel, F. (2008). Can truth be negotiated? History textbook revision as a means to reconciliation. Annals of the American Academy of Political and Social Science, 617, 181-198.

Pingel, F. (2009). From ownership to intervention-or vice versa? Textbook revision in Bosnia and Herzegovina. In A. Dimou (Ed.), "Transition" and the politics of history education in Southeast Europe (pp. 251-305). Göttingen: V\&R Unipress.

Pingel, F. (2010). UNESCO guidebook for textbook research and textbook revision (2nd rev. ed.) Paris: UNESCO with support of Georg Eckert Institute for International Textbook Research.

Ramírez-Barat, C., \& Duthie, R. (2015). Education and transitional justice: Opportunities and challenges for peacebuilding. New York: International Center for Transitional Justice.

Richter, S. (Ed.). (2008). Contested views of a common past: Revisions of history in contemporary East Asia. Frankfurt am Main/New York: Campus.

Rohde, A. (2012). Bridging conflicts through history education? A case study from Israel/Palestine. In S. Alayan, A. Rohde, \& S. Dhouib (Eds.), The politics of education reform in the Middle East: Self and other in textbooks and curricula (pp. 237-260). New York: Berghahn Books. 
Rohde, A. (2013a). Change and continuity in Arab Iraqi education: Sunni and Shi'i discourses in Iraqi textbooks before and after 2003. Comparative Education Review, 57(4), 711-734.

Rohde, A. (2013b). Learning each other's historical narrative: A road map to peace in Israel/Palestine? In K. V. Korostelina \& S. Lässig (Eds.), History education and postconflict reconciliation: Reconsidering joint textbook projects (pp. 177-191). Abingdon, UK: Routledge.

Rüsen, J. (2004). Historical consciousness: Narrative structure, moral function, and ontogenetic development. In P. Seixas (Ed.), Theorizing historical consciousness (pp. 63-85). Toronto: University of Toronto Press.

Sarwary, B. (2012). Why Afghanistan's past is being "rewritten". BBC News. Retrieved July, 3, 2017, from http://www.bbc.com/news/worldasia-18579315.

Schöpflin, G. (1997). The functions of myth and a taxonomy of myths. In G. Hosking \& G. Schöpflin (Eds.), Myths and nationhood (pp. 19-35). London: Hurst.

Seixas, P. (2000). Schweigen! Die Kinder! or does postmodern history have a place in the schools? In P. N. Stearns, S. Wineburg, \& P. Seixas (Eds.), Knowing, teaching and learning history: National and international perspectives (pp. 19-37). New York: University Press.

Seixas, P. (Ed.). (2004). Theorizing historical consciousness. Toronto: University of Toronto Press.

Smith, A. (2010). The influence of education on conflict and peace building, Background paper prepared for the education for all global monitoring report 2011 The Hidden Crisis: Armed conflict and education. Paris: UNESCO. Education For All, Global Monitoring Report. Paris: UNESCO.

Stobart, M. (1999). Fifty years of European co-operation on history-textbooks: The role and contribution of the Council of Europe. Internationale Schulbuchforschung, 21, 147-161.

Stöber, G. (2013). From textbooks comparison to common textbooks? Changing patterns in international textbook revision. In K. Korostelina \& S. Lässig (Eds.), History education and postconflict reconciliation: Reconsidering joint textbook projects (pp. 26-51). London: Routledge.

Stradling, R. (2003). Multi-perspectivity in history teaching: A guide for teachers. Strasbourg: Council of Europe.

Taif Agreement. (1989). Retrieved from http://peacemaker.un.org/lebanontaifaccords89

Torsti, P. (2007). How to deal with a difficult past? History textbooks supporting enemy images in post-war Bosnia-Herzegovina. Journal of Curriculum Studies, 39(1), 77-96.

Torsti, P. (2009). Segregated education and texts: A challenge to peace in Bosnia and Herzegovina. International Journal on World Peace, 26(2), 65-82. 
United Nations Commission on Human Rights. (2005). Updated set of principles for the protection and promotion of human rights through action to combat impunity (E/CN.4/2005/102/Add.1).

UNESCO. (1949). A handbook for the improvement of textbooks and teaching materials as aids to international understanding. Paris: UNESCO.

UNESCO. (2011). The bidden crisis: Armed conflict and educationEducation for all global monitoring report 2011. Paris: UNESCO.

United Nations General Assembly. (2006). The basic principles and guidelines on the right to a remedy and reparations for victims of gross violations of international human rights law and serious violations of international humanitarian $\operatorname{law}(\mathrm{A} / \mathrm{Res} / 60 / 147)$.

Van Ommering, E. (2015). Formal history education in Lebanon: Crossroads, past conflicts and prospects for peace. International Journal of Educational Development, 41, 200-207.

Vickers, E., \& Jones, A. (Eds.). (2005). History education and national identity in East Asia. London: Routledge.

Weldon, G. (2010). A comparative study of the construction of memory and identity in the curriculum in societies emerging from conflict: Rwanda and South Africa. Saarbrücken: Lambert Academic Publishing.

Werner, M., \& Zimmermann, B. (2004). Penser l'histoire croisée: entre empirie et réflecivité (Thinking about entangled history. Between empirical data and reflexivity). In M. Werner \& B. Zimmermann (Eds.), De la comparaison à l'histoire croisée (pp. 15-52) (From comparison to entangled histories). Paris: Seuil.

Wertsch, J. V. (1998). Mind as action. New York: Oxford University Press.

Wertsch, J. V. (2002). Voices of collective remembering. Cambridge, UK: Cambridge University Press.

Williams, J. H. (Ed.). (2014). (Re) constructing memory: School textbooks and the imagination of the nation. Rotterdam: Sense Publishers.

Winslade, J., \& Monk, G. (2000). Narrative mediation. A new approach to conflict resolution. San Francisco: Jossey-Bass.

World Bank. (2005). Reshaping the future: Education and postconflict reconstruction. Washington, DC.: World Bank.

Yang, D., \& Sin, J.-B. (2013). Striving for common history textbooks in Northeast Asia (China, South Korea and Japan): Between ideal and reality. In K. Korostelina \& S. Lässig (Eds.), History education and postconflict reconciliation: Reconsidering joint textbook projects (pp. 209-229). London: Routledge.

Zambylas, M. (2013). Integrated schooling in divided Cyprus: Impossible or indispensable? Studies in Ethnicity and Nationalism, 13(3), 442-454. 


\section{Author Biography}

Denise Bentrovato is a Research Fellow in the Department of Humanities Education at the University of Pretoria and the co-founder and co-director of the African Association for History Education. Her research combines an interest in post-conflict memory politics, transitional justice and history education and primarily focuses on Africa, notably the Great Lakes Region, for which she is a special advisor at the Institute for Historical Justice and Reconciliation in the Netherlands. Throughout her career, she has worked both in academia and for international organisations and NGOs in Europe and Africa, including UNESCO. Dr. Bentrovato holds a Ph.D. in History and an M.A. in Conflict Resolution. Among her most recent publications are Narrating and Teaching the Nation: The Politics of Education in Pre- and Post-Genocide Rwanda (2015) and History Can Bite: History Education in Divided and Postwar Societies [with K. Korostelina and M. Schulze (eds.)] (2016).

Open Access This chapter is licensed under the terms of the Creative Commons Attribution 4.0 International License (http://creativecommons.org/licenses/ by $/ 4.0 /$ ), which permits use, sharing, adaptation, distribution and reproduction in any medium or format, as long as you give appropriate credit to the original author(s) and the source, provide a link to the Creative Commons license and indicate if changes were made.

The images or other third party material in this chapter are included in the chapter's Creative Commons license, unless indicated otherwise in a credit line to the material. If material is not included in the chapter's Creative Commons license and your intended use is not permitted by statutory regulation or exceeds the permitted use, you will need to obtain permission directly from the copyright holder.

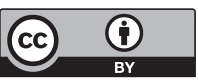

